\title{
Capacity Building and Human Resource Development Initiatives: Community Based Tourism Development in Nepal
}

\author{
Rabi Jung Pandey \\ rabijp@gmail.com
}

\begin{abstract}
Community Based Tourism (CBT) in Nepal is considered one of the important industries for sustainable development and empowerment. The government is apprehensive on promoting this industry with higher priority. With a view, it being an employmentoriented industry there is a notion that it could solve the socio-economic discrepancies, if expanded to many areas of the country. Taking these facts into consideration, it has been initiated to develop community-based tourism with wider objectives. It is also argued that the impacts on livelihoods and not just income need to be assessed along with the variety of positive and negative effects. There is a strong belief that CBT capacitates and empowers local people as actors in tourism planning, development and management. There is a perception among the local stakeholders that CBT helps them understand how tourism could contribute to their well-being and take active roles to minimize the negative impacts of tourism. It is intended that the management, development and ownership of local tourism resources and products should be carried out by the local communities themselves to ensure maximum tourism benefits to the local stakeholders, making them more responsible. Despite the fact that there are numerous training courses being run particularly focused on the tourism development in Nepal, there is still a deficiency of more $\mathrm{CBT}$ related training manuals. Effective teaching and learning process, sharing knowledge and experiences amongst the trainers, participants as well as other stakeholders are still in high demand. Furthermore, proper monitoring and follow-up practices of executed training events are preferred to be ensured.
\end{abstract}

Keywords: Tourism Resource; Capacity Development; Empowerment; Training Manuals

\section{Rural Tourism Initiatives}

Tourism development in Nepal has been visualized as a development tool - not just in promoting tourism growth but also in reducing rural poverty. Though poverty is widespread and pervasive, it is even more acute in the rural/ mountain areas. In the potential areas, tourism is expected to engage them in the higher productivity areas by linking to commercial process, and marketing chain beyond borders (Pandey 2003). 
This is the reason the government of Nepal has given utmost priority to promoting CBT and it has also been perceived that this kind of tourism can play a significant role in the development of rural and mountainous areas of Nepal. With a view that it is an employment oriented industry, it is expected to solve the unemployment problems, if it is expanded to different areas of the country. Taking these facts into consideration, the government in partnership with private sectors and local community has initiated to develop community-based sustainable rural tourism with wider objectives (Pandey 1996, 2003). Nepal's Seventh Plan (1985-90) represents the first attempt to formulate a distinct tourism programme with a long-term prospective for equitable socio-economic distribution. Subsequently, this became one of the major objectives of the Eighth Plan (1992-97) and the Ninth Plan (1997-2002). Consequently, the CBT took a momentum in a planned approach making it a relatively new paradigm for the Nepali tourism industry.

Although the policies and strategies of the Ninth Plan (1997-2002) aimed at achieving broad-based growth and providing basic social services to address various aspects of poverty, this could not succeed to reach large segments of the rural community, notably the poorest of the poor and marginalized groups. As a result, the then government tried to tackle poverty through simultaneous strategies: broad-based economic growth; social sector development; and a set of targeted programmes with the Tenth Plan (2002-2007) and Interim Plan (20082010) as well. Likewise, in the new Tourism Policy 2008 and Tourism Vision 2020, new directives were charted to overcome the problems of endemic poverty, unemployment, regional imbalances and economic and social deprivation and have set up a long-term perspective and twenty-year growth targets (HMG, 1997, 2002, 2003 and GON 2007, 2009).

In order to reap tourism benefits at the community level, various governmental and non-governmental organizations have been working closely with the rural communities. Such organizations with emphasis on various ecotourism activities have established a new frontier in the Nepali tourism history by empowering local people to get involved in community-based ecotourism and thus helping to eradicate poverty from rural areas. Similarly, some institutions are also involved in researching poverty and poverty alleviation, income and employment impacts of tourism. Likewise, others have been engaged in measuring sustainability of mountain tourism, and tourism's contribution to community development.

\section{TRPAP Initiatives - A Pilot Community Based Tourism Programme}

Tourism for Rural Poverty Alleviation Programme (TRPAP) was designed in 2001 to support the government to formulate policies for sustainable tourism development and to create an environment for poverty alleviation in rural areas through community-based tourism. This pilot programme, which was focused on 48 Village Development Committees (VDCs) in six districts, had intended to serve as an appropriate vehicle to provide improvements in living standards 
and achieve sustainable tourism activity. It was focused primarily on the disadvantaged and discriminated sections of Nepal's rural population, especially women, lower caste groups and ethnic minorities who lived below the poverty line. It also provided assistance for the development of institutional mechanisms to ensure sustainability of tourism development through local ownership in terms of decision-making, implementation and operation of tourism ventures/ activities.

In order to gain the widest possible community support, the programme worked closely with the community as a whole. Hence, the model of 'focus groups' rather than 'target groups' was applied. The objective was to provide benefits to all members of the community and also to raise the living standards of the poorer sections. With a view that the benefits of rural-based tourism accrue to both tourists and local inhabitants, local level planning process had been initiated for tourism to create demand for locally produced goods and services and to raise the living standards of rural people by creating off-farm employment and income-generating opportunities. More interestingly the programme intervened on the following major four sectors (TRPAP 2001):

\section{(a) Social Mobilization and Empowerment:}

The social empowerment of rural communities to manage their own tourism development was a key component of this programme. It proposed the social mobilization process within the tourism utilizing it as a vehicle for equitable socio-economic development and allowing communities to contribute to the development of their villages. TRPAP became the first pilot programme that used Appreciative Participatory Planning and Action (APPA) as a social mobilization tool in tourism development in Nepal. APPA was used to develop settlementlevel five-year tourism plans by appreciating communities' strengths and using positive thinking power. The local-level plans were prepared in active participation of communities, using the ' $5 \mathrm{D}$ ' cycle. The 5D stands for discovery, dream, design, direction and delivery. The APPA methodology not only involved local people in the decision-making process, but also empowered them in socio-economic development.

Thus, the programme became the trend setter recommending that before any tourism project is initiated in a rural community, the community should assess and judge for itself whether it could manage the inevitable change that accompanies any project launched in or by the community. The Development Wheel framework was designed to ensure that the 'top-down' decisionmaking by external authorities was replaced by 'bottom-up' approach in the development process and a community's involvement in tourism opportunities by the beneficiaries themselves. 


\section{(b) Decentralised Operational Modality:}

In order to sustain the programme, grassroots level Sustainable Tourism Development Committees (STDCs) were formed and members of them including many others were trained in various sectors to improve their capacity enabling them to understand the importance of tourism and environment, to run their businesses, to derive benefits from tourism and to get them engaged in remunerative employment. To help the local community achieve equitable socio-economic benefits through tourism development, at the village and district levels, the programme also established Sustainable Tourism Village Funds (STVF) and Sustainable Tourism Development Funds (STDF), respectively. These funds provided facility for investment in community-based tourism activities developing strong backward and forward linkages at different levels.

\section{(c) Backward and forward linkages:}

The tourism development process initiated by TRPAP involved many stakeholders providing different products, services and facilities. Joining forces at the community and district levels increased the opportunities for Functional Groups (FGs) to become leading partners in sustainable tourism development process. For this reason, Sustainable Tourism Development Committees (STDCs) at local levels were established to strengthen their linkages between FGs and the private sector. Similarly, backward linkages were strengthened through the social mobilization process (including local-level business-planning and skill development training). Forward linkages were also strengthened by supporting STDCs to develop and conduct marketing activities for the (national-level) private sector.

\section{(d) Sustainable consumption and market linkages:}

TRPAP worked to create linkages between new products it had developed with outside markets. Special attention was paid to the emerging 'responsible tourism' sector including Nepal's Sustainable Tourism Network and on familiarization visits to ground handlers such as tour operators and journalists in the new tourism product areas. In addition to that, various workshops and promotional initiatives were conducted to produce and distribute the promotional documentaries, posters, and brochures.

Nepal Tourism Board (NTB) was pivotal in giving continuity to the promotion of new tourism products developed by TRPAP in Asian, European and American markets. In addition, TRPAP itself participated in international-level tourism fairs and marts.

Thus, TRPAP had been successful to set a model community-based tourism, offering various experiences to tourists while contributing to the socioeconomic development objectives of the government and the Millennium 
Development Goals. Local communities who had never witnessed a trace of tourism activity were now able to provide services transforming their villages into model tourism villages. Active participation of local communities, including women, disadvantaged groups and poor, in tourism development and benefit sharing at local level has thus become exemplary. The raised level of awareness and understanding, skills developed and institutional linkage established with local and national tourism institutions for forward and backward linkages, and mainstreaming tourism in the local self-governance system are some of the successful models of TRPAP (TRPAP 2007). It is evident that others are also replicating TRPAP's community-based tourism model.

\section{HRD Practices and Packages for CBT}

Under the CBT development process in Nepal, there have been efforts in developing CBT-focused training manuals. This is due to the demand of such type of tourism training events in the rural areas. However, the training institutes situated in the urban areas mainly focus on the training courses suitable for the urban/city areas as there is a huge demand for such trained human resources. The key trainings in the urban areas include cookery and bakery, housekeeping, tour guide, front office management, front office and hospitality management, waiter/waitress and air-ticketing et al. Further, the human resources developed by these established tourism colleges are mostly employed by the local tourism industry (hotels, travel/trekking/tour operating agencies) and some have migrated for overseas work opportunities.

There are very few cases where tourism graduates actually go to the rural areas to practice their expertise/skills. This is due to the less attraction owing to the low payment rates, limited opportunities and demands as well as the less interest of the professionals to work in the rural and remote parts. Further, it could have been caused by the fact that most of the rural businesses are run by family members and they rarely require professional staff from outside.

The rural entrepreneurs most often look for low or semi-skilled workers from the same locality or surroundings. This is in response to cost-saving mechanism and reducing the risk of over expenses on management. Considering this, there have been several demands for short training courses and in most cases they demand for practical problem-oriented (also called tailor-made) training events suitable to that particular locality. Such courses mainly include small hotel and lodge management, cooking, bakery, hospitality and management, front office management and entrepreneurship development et al.

TRPAP during the programme period also made efforts towards developing tourism training manuals. The project developed different types of training manuals focusing on different subjects related to community-based tourism development in Nepal (Table 1). 


\begin{tabular}{|l|l|}
\hline \multicolumn{1}{|c|}{ SN } & \multicolumn{1}{|c|}{ Title of the Manual } \\
\hline 1. & $\begin{array}{l}\text { Tourism Education Pictorials (4 types/sets) with Facilitator's Manuals, } \\
2002\end{array}$ \\
\hline 2. & Sustainable Tourism Education Booklet in Nepali Language \\
\hline 3. & Eco-Tourism \& Biodiversity Conservation (Training Manual), 2005 \\
\hline 4. & Waste Management in the Rural Tourism Areas: Training Manual -2005 \\
\hline 5. & Solar Drying Resource Manual in Nepali Language \\
\hline 6. & Gender, HIV/AIDS and Tourism Training Manual in Nepali Language \\
\hline 7. & Gender, HIV/AIDS and Tourism Resource Manual in Nepali Language \\
\hline 8. & APPA Facilitator's Manual, 2006 in Nepali Language \\
\hline 9. & $\begin{array}{l}\text { Tourism \& Environment Awareness Training Manual, 2005 in Nepali } \\
\text { Language }\end{array}$ \\
\hline 10. & $\begin{array}{l}\text { Management Capacity Enhancement, Training Manual, 2005 in Nepali } \\
\text { Language }\end{array}$ \\
\hline 11. & $\begin{array}{l}\text { Small Hotel \& Lodge Management Training Manual, 2005 in Nepali } \\
\text { Language }\end{array}$ \\
\hline 12. & Cooking \& Baking, Training Manual, 2005 in Nepali Language \\
\hline 13. & Local Tour Guide (Training Manual), 2005 \\
\hline
\end{tabular}

Table 1: Training Manuals Developed by TRPAP

\section{Source: TRPAP 2007}

It is observed that, the manuals prepared by TRPAP being approved by the government, Ministry of Tourism and Civil Aviation (MoTCA), were considered to be the model manuals. While developing these manuals, the governmentrun tourism training institution called Nepal Academy of Tourism and Hospitality Management (NATHM) also got the opportunity to reorient its technical staff on rural tourism/CBT through various types of trainings, workshops, interactions and exposure visits provided by the TRPAP.

Available literature shows that there are 32 types of training packages presently being run in the tourism areas also targeting the CBT development process in 
Nepal (Table 2). These training packages are offered by different institutions with different modular approaches (Pandey 2008).

It is very interesting to note that the tourism education and training activities are drastically booming in Nepal. There are more than half a dozen colleges and dozens of private companies that offer tourism education and tourism-related short training courses. Some of the tourism colleges even offer the courses directly affiliating with international colleges.

It is claimed that all types of training packages currently run by various institutions are focused on the local community/people, tourism entrepreneurs/ professionals and tourism development workers. However, these trainings can be broadly classified into six main disciplines related to tourism development and management, viz:

I) Trekking, Mountaineering and Tour Guide (Nature, Culture, Heritage)

II) Travel/Tour and Hospitality Management

III) Food/Lodge (Accommodation) Services

IV) Destination Planning, Development and Management

V) Tourism Interpretation, Promotion and Marketing

VI) Enterprise/Entrepreneurship/Leadership Development \& Management

Among the non-governmental organizations (NGOs), the Kathmandu Environmental Education Project (KEEP) had operated a few training programmes on tourism and environment in Nepal. It has been active for almost 12 years and still conducts various types of short-term tourism training programmes at different places of Nepal. So far, KEEP has conducted various training courses in Kathmandu, Rasuwa, Solukhumbu, Sindhupalchowk, Pokhara and Dolpa. The trainings mainly focus on sustainable and environmental issues in tourism, waste management and sanitation, visitor information centre management, first aid, English/German languages for guides, leadership development, heritage and hospitality management and eco-trekking.

The training duration of the above mentioned courses is three to seven days, depending on the availability of resources, locality, and the types of training courses. Further, the duration is also determined by the level and other qualifications of the training participants. 


\begin{tabular}{|c|c|c|c|c|}
\hline $\begin{array}{l}\mathbf{S} \\
\mathbf{N}\end{array}$ & $\begin{array}{l}\text { Name of the training } \\
\text { course }\end{array}$ & Duration & $\begin{array}{c}\text { Special target groups } \\
\text { of the training }\end{array}$ & Training providers \\
\hline \multicolumn{5}{|c|}{ Trekking/Mountaineering/Tour Guiding (Nature, Culture, Heritage) } \\
\hline & $\begin{array}{l}\text { Tour/Local Tour } \\
\text { Guide }\end{array}$ & 2 weeks & $\begin{array}{l}\text { Interested persons in } \\
\text { guiding }\end{array}$ & PTTC \\
\hline & Mountaineering & $\begin{array}{l}\text { Various } \\
\text { duration }\end{array}$ & $\begin{array}{l}\text { Climbers, } \\
\text { Mountaineering Guides }\end{array}$ & $\begin{array}{l}\text { Nepal } \\
\text { Mountaineering } \\
\text { Instructors' } \\
\text { Association (NMIA) }\end{array}$ \\
\hline & $\begin{array}{l}\text { Training on Religions } \\
\text { to Guides }\end{array}$ & 5-7 days & Guides & TURGAN, \\
\hline & $\begin{array}{l}\text { Senior River Guide } \\
\text { (Higher Level) }\end{array}$ & 1 week & S.L.C. pass & NATHM/NARA \\
\hline & $\begin{array}{l}\text { Junior River Guide } \\
\text { (Middle Level) }\end{array}$ & 2 weeks & S.L.C. pass & NATHM/NARA \\
\hline & $\begin{array}{l}\text { River Guide (Basic } \\
\text { Level) }\end{array}$ & 5 weeks & Literate & NATHM/NARA \\
\hline \multicolumn{5}{|c|}{ II. } \\
\hline & $\begin{array}{l}\text { Front Office (Desk) } \\
\text { Operation/Hotel } \\
\text { Reception }\end{array}$ & 7 Months & SLC & $\begin{array}{l}\text { PTTC, Private } \\
\text { institutions }\end{array}$ \\
\hline & $\begin{array}{l}\text { Travel Trade } \\
\text { (Agency) Operations }\end{array}$ & 1 to 9 months & Graduates & $\begin{array}{l}\text { KATH, Private } \\
\text { institutes }\end{array}$ \\
\hline & $\begin{array}{l}\text { Tour Package } \\
\text { Designing and } \\
\text { Costing }\end{array}$ & 1 week & $10+2$ pass & KATH \\
\hline & Airlines Ticketing & $\begin{array}{l}1 \text { week to } 3 \\
\text { months }\end{array}$ & SLC & $\begin{array}{l}\text { PTTC, Private } \\
\text { institutions, KATH }\end{array}$ \\
\hline & $\begin{array}{l}\text { IATA Basic Training } \\
\text { (Ticketing and Fare } \\
\text { Construction) }\end{array}$ & 1 week & BA & NATTA \\
\hline \multicolumn{5}{|c|}{ III. } \\
\hline & $\begin{array}{l}\text { Cooking/Bakery } \\
\text { (Food Preparation } \\
\text { and Control) }\end{array}$ & $\begin{array}{l}10 \text { days to } 1 \\
\text { month }\end{array}$ & 8 class passed & $\begin{array}{l}\text { PTTC, Private } \\
\text { institutions }\end{array}$ \\
\hline & $\begin{array}{l}\text { Hotel/Lodge } \\
\text { Management* }\end{array}$ & $1-2$ weeks & SLC & $\begin{array}{l}\text { PTTC, Private } \\
\text { institutions }\end{array}$ \\
\hline & Butchery & 1 week & $\begin{array}{l}\text { Interested butcher/ } \\
\text { kitchen staff }\end{array}$ & KIHM \\
\hline & $\begin{array}{l}\text { Waiter/Waitress } \\
\text { (Food and Bev. } \\
\text { Service) }\end{array}$ & $\begin{array}{l}2 \text { weeks to } \\
6 \text { months }\end{array}$ & 10 class passed & $\begin{array}{l}\text { PTTC, Private } \\
\text { institutions }\end{array}$ \\
\hline & Dining Etiquette & 1 day & Parliamentarians, VIPs & Silver Mountain \\
\hline
\end{tabular}


Nepal Tourism \& Development Review (Volume 1, Issue 1, 2011) । 91

\begin{tabular}{|c|c|c|c|c|}
\hline & Housekeeping & 3-6 months & Housekeeping staff & $\begin{array}{l}\text { PTTC, Private } \\
\text { institutions }\end{array}$ \\
\hline & Bartender & 2 weeks & 10 class passed & $\begin{array}{l}\text { PTTC, Private } \\
\text { institutions }\end{array}$ \\
\hline & Bell person (boy) & 2 weeks & 10 class passed & PTTC \\
\hline & Hotel Representative & 1 week & SLC & PTTC \\
\hline & Customer Care & 1 week & $\begin{array}{l}\text { Hotel and Travel Agency } \\
\text { Staff }\end{array}$ & KATH \\
\hline & Domestic Helper & 8 weeks & 8 class passed & PTTC \\
\hline \multicolumn{5}{|c|}{ evelopment and Manag } \\
\hline & \begin{tabular}{|l} 
Tourism and \\
Environment \\
Awareness (TEAP \\
Training \\
\end{tabular} & 2-3 days & Local stakeholders & NTB \\
\hline & $\begin{array}{l}\text { Sustainable Tourism } \\
\text { Development and } \\
\text { Management }\end{array}$ & 1 week & $\begin{array}{l}\text { Tourism development } \\
\text { workers, professionals }\end{array}$ & KATH \\
\hline & $\begin{array}{l}\text { Tourism Development } \\
\text { Planning }\end{array}$ & $\begin{array}{l}\text { Various } \\
\text { duration }\end{array}$ & $\begin{array}{l}\text { Tourism development } \\
\text { workers/professionals }\end{array}$ & KATH \\
\hline & \begin{tabular}{|l|} 
Eco-tourism \\
and Biodiversity \\
Conservation (ToT)
\end{tabular} & 15 days & $\begin{array}{l}\text { Development Workers, } \\
\text { Trainers }\end{array}$ & DNPWC \\
\hline & $\begin{array}{l}\text { Eco-tourism } \\
\text { Development }\end{array}$ & 1 month & Development workers & NCTTM \\
\hline & \begin{tabular}{|l} 
Tourism \\
Measurement
\end{tabular} & $\begin{array}{l}\text { Various } \\
\text { duration }\end{array}$ & Tourism professionals & KATH \\
\hline \multicolumn{5}{|c|}{ otion \& Marketing } \\
\hline 29. & \begin{tabular}{|l} 
Visitor Information \\
Centre (VIC) \\
Management \\
\end{tabular} & 1 week & $\begin{array}{l}\text { Persons affiliated with } \\
\text { VIC management }\end{array}$ & KEEP \\
\hline 30. & Tourism Marketing & $\begin{array}{l}\text { Various } \\
\text { duration }\end{array}$ & $\begin{array}{l}\text { Tourism development } \\
\text { workers/professionals }\end{array}$ & KATH \\
\hline \multicolumn{5}{|c|}{ DEVEIOPIII } \\
\hline 31. & $\begin{array}{l}\text { Hotel and Travel } \\
\text { Trade Account } \\
\text { Keeping }\end{array}$ & 3-5 days & $\begin{array}{l}\text { Hotel staff, Travel/Trade } \\
\text { staff, other interested }\end{array}$ & KATH \\
\hline 32. & $\begin{array}{l}\text { Tourism Enterprise } \\
\text { Development } \\
\text { Training }\end{array}$ & 5-7 days & $\begin{array}{l}\text { Tourism entrepreneurs, } \\
\text { development workers } \\
\text { etc. }\end{array}$ & IIED \\
\hline
\end{tabular}

Table 2: Tourism training packages offered by various institutions Source: Pandey 2008

Table 2 reveals that there are 32 types of training packages ranging from one day to nine months duration. The majority of the training courses are offered by 
NATHM together with some private institutions that have opened recently. In addition to some of the tourism colleges and offered academic courses, they also offer a few specific tailor-made tourism trainings upon special demands.

The academic courses being run by various colleges include $10+2$ in Hotel Management (HM), Certificate in Food and Beverage Management (F\&BM), Diploma/Post Graduate Diploma in HM/Tourism Management, Bachelors in Hotel Management (BHM), Bachelors in Travel and Tourism Management (BTTM)/ Bachelors in Travel and Tourism Studies (BTTS), Bachelors in Science (Honours) in Hospitality Management, B.Sc. (Honours) in Culinary Art Management, Bachelors in Business Administration in HM, Masters in Tourism Studies (at KATH), Masters in Tourism Management (proposed by NCTTM), Masters in Tourism and Hospitality Management (proposed by NATHM \& ISTHM) (NATHM 2008, PTTC 2008, NTHMC 2008).

\begin{tabular}{|c|c|c|c|}
\hline S.N. & Title/Types of Courses & Duration & Minimum criteria for the participants \\
\hline A. & \begin{tabular}{|l} 
Bachelors in Hotel \\
Management (BHM)
\end{tabular} & 3 yrs & $\begin{array}{l}10+2 \text { or equivalent with minimum } 45 \% \text { in } \\
\text { aggregate marks }\end{array}$ \\
\hline B. & $\begin{array}{l}\text { Bachelor in Travel and } \\
\text { Tourism Management } \\
\text { (BTTM) }\end{array}$ & 3 yrs & $10+2$ or equivalent \\
\hline \multicolumn{4}{|c|}{ C. Hotel Sector Basic Training } \\
\hline 1 & $\begin{array}{l}\text { Food Preparation \& } \\
\text { Control }\end{array}$ & 9 months & S.L.C. Pass \\
\hline 2 & $\begin{array}{l}\text { Food \& Beverage } \\
\text { Service }\end{array}$ & 6 months & S.L.C. Pass \\
\hline 3 & Housekeeping & 6 months & Test Pass \\
\hline 4 & Front Office Operation & 7 months & I.A. Pass or Equivalent \\
\hline \multicolumn{4}{|c|}{ In-service Training (Basic) } \\
\hline 5 & $\begin{array}{l}\text { Food Preparation \& } \\
\text { Control }\end{array}$ & 4 weeks & $\begin{array}{l}\text { Employed in industry \& must have 1-year } \\
\text { experience }\end{array}$ \\
\hline 6 & $\begin{array}{l}\text { Food \& Beverage } \\
\text { Service }\end{array}$ & 4 weeks & $\begin{array}{l}\text { Employed in industry \& must have } 6 \text { months } \\
\text { experience }\end{array}$ \\
\hline 7 & Housekeeping & 4 weeks & - do- \\
\hline 8 & Front Office & 4 weeks & $\begin{array}{l}\text { S.L.C. pass with 1-year experience in tourist } \\
\text { standard hotel }\end{array}$ \\
\hline 9 & Bar Man & 2 weeks & $\begin{array}{l}\text { Employed in the hotel industry \& must have } \\
1 \text {-year experience }\end{array}$ \\
\hline \multicolumn{4}{|c|}{ Supervisor Training } \\
\hline 10 & $\begin{array}{l}\text { Food Preparation and } \\
\text { Control }\end{array}$ & 3 weeks & $\begin{array}{l}\text { S.L.C. pass with 5-year experience in related } \\
\text { field }\end{array}$ \\
\hline
\end{tabular}




\begin{tabular}{|c|c|c|c|}
\hline 11 & $\begin{array}{l}\text { Food \& Beverage } \\
\text { Service (Captain) }\end{array}$ & 6 months & $\begin{array}{l}\text { 1-year experience with basic training from } \\
\text { NATHM or work experience as a waiter } \\
\text { trainee captain or barman with S.L.C. pass }\end{array}$ \\
\hline 12 & Housekeeping & 6 months & $\begin{array}{l}\text { I.A. pass or S.L.C. with basic training from } \\
\text { NATHM and } 1 \text {-year experience in } 3 \text { to } 5 \text { star } \\
\text { hotel }\end{array}$ \\
\hline \multicolumn{4}{|c|}{ D. Tour/Travel \& Trekking Sector } \\
\hline 13 & Tourist Guide & 10 weeks & Graduate in any discipline \\
\hline 14 & $\begin{array}{l}\text { Tourist Guide Refresher } \\
\text { Course }\end{array}$ & 1 week & Minimum 3 years of guiding experience \\
\hline 15 & $\begin{array}{l}\text { Travel Agency } \\
\text { Ticketing and Fare } \\
\text { Construction }\end{array}$ & 24 weeks & I.A. pass or equivalent \\
\hline 16 & $\begin{array}{l}\text { In-service Ticketing } \\
\text { for travel agency } \\
\text { personnel }\end{array}$ & 2 weeks & $\begin{array}{l}\text { I.A. pass or equivalent with } 1 \text {-year working } \\
\text { experience in travel trade area recommended } \\
\text { by NATA. }\end{array}$ \\
\hline 17 & Trekking Cook \& Waiter & 4 weeks & $\begin{array}{l}\text { Able to understand and speak Nepali and } \\
\text { English and should have } 1 \text { year of cooking } \\
\text { experience in a trekking agency }\end{array}$ \\
\hline 18 & Trekking Guide & 6 weeks & $\begin{array}{l}\text { Able to understand and have basic knowledge } \\
\text { of English communication with } 2 \text { years of } \\
\text { work experience }\end{array}$ \\
\hline 19 & $\begin{array}{l}\text { Senior River Guide } \\
\text { (Higher Level) }\end{array}$ & 1 week & $\begin{array}{l}\text { S.L.C. pass with 2-year work experience on } \\
\text { river as a trainee between } 18-30 \text { years of age, } \\
\text { certified by NARA }\end{array}$ \\
\hline 20 & $\begin{array}{l}\text { Junior River Guide } \\
\text { (Middle Level) }\end{array}$ & 2 weeks & $\begin{array}{l}\text { S.L.C. pass with } 12 \text { years of work } \\
\text { experience in rafting as a river guide or in } \\
\text { the management position in Rafting Agency } \\
\text { recommendation from NARA }\end{array}$ \\
\hline 21 & $\begin{array}{l}\text { River Guide (Basic } \\
\text { Level) }\end{array}$ & 5 weeks & $\begin{array}{l}\text { Able to read, write and communicate in } \\
\text { English with } 2 \text { years of working experience, } \\
\text { sound knowledge of swimming and } \\
\text { recommendation from NARA }\end{array}$ \\
\hline \multicolumn{4}{|c|}{ E. Other Training } \\
\hline 22 & $\begin{array}{l}\text { Mobile Outreach } \\
\text { Training (On-the-spot } \\
\text { training in tourist area) }\end{array}$ & 10 days & Working in related field \\
\hline 23 & Housewife & $2 \frac{1}{2}$ weeks & Should be able to read and write Nepali \\
\hline 24 & Hotel Maintenance & 2 weeks & Working in the same field in a hotel \\
\hline 25 & Indian Cookery & 3 months & S.L.C. Pass \\
\hline 26 & Chinese Cookery & 3 months & S.L.C. Pass \\
\hline
\end{tabular}

Table 3: Training packages offered by NATHM (including academic courses) Source: Pandey 2008 
NATHM, in addition to the two academic courses (BHM and BTTM), has special mandate from the government to run short training courses targeting towards rural destinations and the people from disadvantaged communities including women, Dalits and conflict-affected people from different parts of the country. As per the mandate, NATHM also provides training scholarships for women on small hotel/lodge management and trekking guide training et al. Among the institutions, NATHM runs a range of courses that include some two dozen tourism training courses available in Nepal (Table 3) (NATHM 2008).

\section{Indirectly-related training packages/courses offered}

As tourism is a vital, integrated and complex industry, it accommodates a wide range of subjects that compliment overall tourism development. There are a number of subjects which are not directly associated with the tourism business/ management but have vital supplementary role (milk, meat, vegetable, fruits, handicrafts, etc) to play for the environment-friendly sustainable tourism development of any destination. At present, for inclusive economic growth, it is found that there are many types of 'indirectly' related trainings that are seen to deliver in the rural tourism areas.

The trainings under this category are broadly classified in four major themes viz.:

1) Agriculture and livestock-based products-focused trainings

2) Crafts productions and sales-related training III) Management capacity and leadership enhancement trainings

3) Conservation, waste management and other trainings as indicated in Table 4 below.

\section{Agriculture \& Livestock-based Products-focused Trainings}

1. Vegetables and Fruits Production (organic)

2. Buffalo/Goat Farming

3. Poultry Farming

4. Milk Products Production (curd, khuwa, chhurpi etc.)

5. Bee-keeping

6. Fruits and Vegetables Processing and Packaging

7. Flower Production (floriculture)

2. Crafts Productions and Sales Related Trainings

8. Handicrafts/Souvenir Items Production and Selling

9. Cultural Show/Choreography

3. Management Capacity Enhancement Related Trainings

10. Computer/Internet 
11. English, Japanese, Chinese, Italian, French, Thai, Korean, Russian, Spanish, and other important languages

12. Managerial Skills

13. Leadership and Networking Skills

14. Conflict Management/Negotiation Skills

15. Savings \& Credit/Micro-funds Management

16. Office Management Skills

17. Secretarial Services

4. Conservation, Waste Management \& other Trainings

18. Waste Management Training

19. Guidelines for Biodiversity Monitoring in Protected Areas (NTNC)

20. Conservation Education (with Resource Book)

21. Alternative Energy/Improved Cooking Stoves

22. First Aid Training

23. Religion and Religious Sites (specific site-focused)

Table 4: Indirectly related training packages/courses

Source: Pandey 2008

\section{Types of Training Manuals Developed and Institutions Involved:}

It is evident by now that there are limited institutions engaged in the development of tourism training manuals. Among the development organisations, the ICIMOD, SNV-Nepal, TRPAP, DNPWC, ACAP and KEEP have contributed significantly in this area in the past decade.

Among the training institutes, NATHM has been active in developing tourism training manuals in the recent years, typically for its 'mobile' training courses, in partnership with TRPAP (2002-2007). This institution is still seen using the training manuals developed by ILO supports (in the late 1990s) and the new manuals developed in partnership with TRPAP (during 2005/06). All these training manuals include both the tourism-related and supportive-type of training courses (NATHM 2008). There are at least seven other types of training manuals which include trainers' manuals and resource books (participants' books) developed by various institutions other than that produced by TRPAP (Table 5). 


\begin{tabular}{|c|c|c|c|}
\hline $\begin{array}{l}\mathbf{S} \\
\mathbf{N}\end{array}$ & $\begin{array}{l}\text { Title of the Manual } \\
\text { (including Guide } \\
\text { Book/Resource Book) }\end{array}$ & $\begin{array}{c}\text { Developed/ } \\
\begin{array}{c}\text { Published } \\
\text { by }\end{array}\end{array}$ & Key Contents of the Manual \\
\hline & $\begin{array}{l}\text { Responsible Trekking } \\
\text { in the Himalayas } \\
\text { (Resource Book) }\end{array}$ & KEEP & $\begin{array}{l}\text { Basic codes of conduct for trekkers in the } \\
\text { Mountains and Himalayas; positive and negative } \\
\text { impacts of tourism, etc. }\end{array}$ \\
\hline & $\begin{array}{l}\text { Nepal Mountaineering } \\
\text { Guide Book, in Nepali } \\
\text { Language }\end{array}$ & $\begin{array}{l}\text { NMIA and } \\
\text { Eco-Himal }\end{array}$ & $\begin{array}{l}\text { Equipment, Knots, Use of Equipment and Knots, } \\
\text { Direction, Rescue Operation Techniques, Dangers } \\
\text { and Safety, Avalanches, Awareness and Safety } \\
\text { Measures, Acute Mountain Altitude Sickness } \\
\text { (AMS), First Aid, GyamoCONFIRM Bag, Rules and } \\
\text { Regulations, Minimum Impacts and Sustainable } \\
\text { Tourism. }\end{array}$ \\
\hline & $\begin{array}{l}\text { Nepal The Living } \\
\text { Heritage (Resource } \\
\text { Book) }\end{array}$ & KEEP & $\begin{array}{l}\text { Importance of heritages, heritage sites, key issues } \\
\text { of heritage preservation, etc. }\end{array}$ \\
\hline & $\begin{array}{l}\text { First Aid and } \\
\text { Wilderness } \\
\text { Medicines (Resource } \\
\text { Book) }\end{array}$ & KEEP & $\begin{array}{l}\text { Introduction to first aid, techniques, wilderness } \\
\text { trekking, possible problems, their treatment etc. }\end{array}$ \\
\hline & $\begin{array}{l}\text { Mountain Tourism for } \\
\text { Local Development: } \\
\text { Training Manual for } \\
\text { Policy Planners in } \\
\text { Tourism and Related } \\
\text { Areas }\end{array}$ & $\begin{array}{l}\text { ICIMOD } \\
\text { /CRES }\end{array}$ & $\begin{array}{l}\text { Overview of Tourism, Mountain Tourism Impacts } \\
\text { and Issues, Sustainable Mountain Tourism } \\
\text { Development (SMTD), Planning and Management } \\
\text { of SMTD, Importance and Utility of Monitoring } \\
\text { and Evaluation, Educating Visitors, Questions for } \\
\text { Discussions, Reading Materials. }\end{array}$ \\
\hline & $\begin{array}{l}\text { Mountain Tourism for } \\
\text { Local Development: } \\
\text { Training Manual for } \\
\text { Programme Designers } \\
\text { and Implementers }\end{array}$ & $\begin{array}{l}\text { ICIMOD/ } \\
\text { CRES }\end{array}$ & $\begin{array}{l}\text { Overview of Tourism, Mountain Tourism Impacts, } \\
\text { Sustainable Mountain Tourism Development } \\
\text { (SMTD), Planning and Management of SMTD, } \\
\text { Technologies for Mountain Environmental } \\
\text { Management, Promoting Community Participation } \\
\text { in Mountain Tourism Planning, Participatory } \\
\text { Planning, Information Needs and Designing } \\
\text { Surveys, Monitoring and Evaluation, Educating } \\
\text { Visitors, Questions for Discussions, Reading } \\
\text { Materials. }\end{array}$ \\
\hline & $\begin{array}{l}\text { Mountain Tourism for } \\
\text { Local Development: } \\
\text { Training Manual for } \\
\text { Local Community } \\
\text { Groups and } \\
\text { Organisations }\end{array}$ & $\begin{array}{l}\text { ICIMOD/ } \\
\text { CRES }\end{array}$ & $\begin{array}{l}\text { Introduction and Tourism Awareness, Mountain } \\
\text { Tourism Impacts, Opportunities and Limitations, } \\
\text { Participatory Planning (PP) of Mountain Tourism, } \\
\text { Grassroots Institutions for PP of Tourism at the } \\
\text { Local Level, Use of Alternative Sources of Energy } \\
\text { and Technology, Management of Solid Waste } \\
\text { and Garbage and Management of Lodges and } \\
\text { Campsites, Local-level Enterprise Opportunities, } \\
\text { Monitoring and Evaluation Educating Visitors, } \\
\text { Questions for Discussions, Reading Materials. }\end{array}$ \\
\hline
\end{tabular}

Table 5: Types of training manuals developed by other institutions 
Accordingly, the International Centre for Mountain Development (ICIMOD), in partnership with CRES (Centre for Resource and Environmental Studies) has developed a set of three training manuals entitled "Mountain Tourism for Local Development" (Baskota and et al 1998). These manuals have been taken as a useful tool for the tourism development process involving local people. These three sets of manuals were targeted to the policy planners, programme designers and implementers and to the local people who are directly involved for themselves through community-based organizations (CBOs).

Similarly, ICIMOD (in partnership with SNV Nepal and Nepal Tourism Board) has developed a set of training manuals (in two volumes) entitled "Facilitating Sustainable Mountain Tourism" (ICIMOD 2008). The first volume is "Resource Book' and, the second volume is 'Toolkit'. These manuals have been developed after the experiences gained by implementing TRPAP project (MoTCA, UNDP, DFID, SNV, NTB, DNPWC) and after the successfully running of an International (ToT) Training in Kathmandu (ICIMOD premise), entitled "Managing Sustainable Tourism Development Projects" in June 2006.

Similarly, SNV Nepal has developed a training facilitation manual in the year 2004 entitled, "Developing Sustainable Communities: A Toolkit for Development Practitioners" (SNV 2004). This manual, which is based on an appreciative inquiry (AI) model, was primarily focused on the rural development facilitators who need to be continuously involved in the community planning and development process.

\section{Major Problems and Gaps observed}

Pondering over the developed manuals and the training practices followed so far for CBT in Nepal, it is found that there exists a number of problems and gaps. The problems associated with the training management, manual development and their execution are summarized below:

\section{A. Training Management/Delivery/Effectiveness:}

- Lack of proper identification of training needs

- Standard modular course/manuals and materials/equipment are lacking

- Most of them are urban tourism-focused

- Most of the packages and materials are old and they lack timely revisions

- Lack of expertise, experience and confidence in trainers

- $\quad$ Lack of awareness in public regarding training on tourism in overall

- Less linkages, coordination and networking between the training institutes and job providers

- Lack of trained human resources, practical approaches and laboratories

- Monitoring/follow-up problems 
- $\quad$ Lack of upgrading training courses

- Poor exposure of the trainers to real world/new destinations

- Problem with standardization/skill testing and certification

\section{B. Training Manuals Development, Execution \& Follow-up}

- $\quad$ Lack of trainers/resource persons to deal with CBT training and manuals in Nepal

- $\quad$ No institution is giving priority to develop training manuals

- No one knows who is doing (using) what

- Present manuals are not covering the emerging issues such as social inclusion, responsible tourism products and services, product standardization et al

\section{Conclusions \& Recommendations}

The study, reveals that the only national tourism organization, Nepal Tourism Board having multiple roles to play needs to take a crucial part of facilitating the concerned institutions/individuals in developing appropriate manuals/ learning materials focusing on CBT. This process would further help streamlining the tourism training (HRD) activities in close coordination with other leading tourism training institutions in Nepal. Below, recommendations are made in two categories: General and Specific.

\section{General:}

1. Trainings must be tailor-made and as per the need of local tourism entrepreneurs/professionals. Participants' feedback from each training programme should be the main basis for further polishing the training packages and manuals. Equally, there should be a continuity of identification, development and implementation of the training programmes in the rural parts where CBT initiatives have taken momentum. For such endeavours, effective coordination must be imparted for local community to identify training needs and relevant activities.

\section{Specific:}

2. Tourism training manual-making initiatives and experiences of different institutions or organizations need to be encouraged and should be continued with a long-term partnership with Nepal Tourism Board. NTB should facilitate and streamline such activities as a national tourism organisation. Though TRPAP does not exist now, its best practices in training manual development processes should be continued with NTB and NATHM as both the organisations were in regular attachments during the TRPAP implementation processes (2002-2007). Further, the training manuals developed by TRPAP need to be revised and reprinted as there is a huge demand for such manuals from various organisations and individuals 
involved in tourism training. NATHM should make more efforts in marketing its 35-year experience in providing training as a pioneer college/training institute in Nepal. It has been almost 25 years since NATHM started its mobile training on cooking and hospitality in the rural and remote parts of the country. However, as anticipated, such experiences have not been fully exploited by NATHM.

3. Nepal Tourism Board should facilitate or provide support to tourismrelated organisations in order to develop training manuals directly related to CBT. In the case of indirectly related training packages and manuals (for example: Effective Social/Community Mobilization, Basic English for Tourism Entrepreneurs and Professionals, Leadership Development Training Manual; Establishing, Operating and Managing Communication Centre, Organic Farming, Dairy Products, Conservation of Nature and Natural Resources, etc.) NTB should not be financially indulged as there are enormous possibilities of getting such packages and manuals from dozens of organisations through an appropriate outsourcing. Concerned District Development Committees (DDCs)/Village Development Committees (VDCs) or Community Based Organisations (CBOs) can locally/regionally or nationally consult for such packages without any difficulty as numerous NGOs and private companies offer the desired/tailor-made courses. Further, it is recommended with the justification that, tourism being a complex industry, there is no limit to be involved in indirectly related training packages/manuals development process.

4. Academic institutions, including NATHM, should play more active roles in developing appropriate manuals related to CBT trainings in Nepal. While doing so, collaborations with NTB and CTEVT are of paramount importance. Some NGOs and INGOs (as mentioned in many instances) have comparatively better experiences in this regard. Hence, their experiences should be fully utilized by the national authorities with appreciation and partnerships.

5. Provision of trainers' training (if possible, Master ToT) on various subjects related to CBT through NTB and NATHM or other tourism institutions would be very fruitful to mainstream CBT in Nepal. Once such trainers and resource persons are developed, a systematic mechanism of needs assessment on CBT, curricula development, manuals development, effective implementation of the developed manuals and their proper follow-up/ monitoring could be ensured. This will obviously help enhance the quality of CBT trainings in Nepal. 


\section{References}

Banskota, K. and Sharma, B. (1998). Mountain Tourism for Local Development: Training Manual for Programme Designers and Implementers, ICIMOD \& CRES, Kathmandu, Nepal Banskota, K. and Sharma, B. (1998). Mountain Tourism for Local Development: Training Manual for Policy Planners and Related Areas, ICIMOD \& CRES, Kathmandu, Nepal

Banskota, K. and Sharma, B. (1998). Mountain Tourism for Local Development: Training Manual for Local Community groups and Organisations, ICIMOD \& CRES, Kathmandu, Nepal

CBS, (1999). Nepal Labour Force Survey 1998/99 - Statistical Report, HMG, National Planning Commission Secretariat, Kathmandu

CTEVT (2008), Skill Testing Brochure, Council for Technical Education and Vocational Training (CTEVT), Sano Thimi, Bhaktapur, Nepal

GON (2007). Three Year Interim Plan (2007/08-2009/10), Kathmandu: National Planning Commission (NPC)

GON (2009). Tourism Policy 2065 BS. Kathmandu: Ministry of Tourism and Civil Aviation (MOTCA)

H.M.G., (1997). The Ninth National Plan (1997 - 2002). Kathmandu: National Planning Commission.

H.M.G., (2002). The Tenth Plan (2002-2007). Kathmandu: National Planning Commission. H.M.G., (2003). The Tenth Plan- Poverty Reduction Strategy Paper (2002-2007). Kathmandu: National Planning Commission.

ICIMOD, (2008). Facilitating Sustainable Mountain Tourism, International Centre for Mountain Development (ICIMOD), Kathmandu, 2008

Lamichhane, RH and Paudel, DP (2005). A Text Book on Food and Beverage Service. Published by the Authors/CTEVT, PTTC, Pokhara, Nepal

MoTCA (2009). Nepal Tourism Statistics- 2009, Ministry of Culture, Tourism and Civil Aviation, Kathmandu, Nepal

NATHM (2008). 35 Years of NATHM (Souvenir), Nepal Academy of Tourism and Hotel Management, Rabi Bhawan, Kathmandu, Nepal

NPC (2001). Census 2001

NPC (2007). Three Year Interim Plan (2007/08-2009/10), Government of Nepal, National Planning Commission

NTB (2001), Sustainable Tourism Network, A Booklet published by Nepal Tourism Board. NTB (2010). Tourism Statistics 2009, Nepal Tourism Board 
NTHMC (2008). Introductory Booklet. Nepal Tourism and Hotel Management College, Pokhara, Nepal.

Pandey, R.J. (1996), Rural tourism: A special concept, The Kathmandu Post, Vol. IV, No. 167.

Pandey, R.J. (1997), Developing Tourism as Community Industry, The Kathmandu Post, Vol. IV, No. 321.

Pandey, R.J. (2003), Rural Tourism Embraces Sustainability and the Poor, Sustainability: The Lasting Fuel for Sustainable Development - Nepal, 2003.

Pandey, R.J. (2006), Challenges in Managing Community Based Ecotourism Projects (A case of TRPAP), Paper presented at the $4^{\text {th }}$ Asia Pacific Ecotourism Conference (APECO), Malaysia, Nov. 2-5, 2006.

Pandey, R. J. (2008). 'Identifying Needs for Developing Training Manuals for CBRT Development in Nepal', Kathmandu: Nepal Tourism Board

PTTC (2008), Prospectus. Pokhara Tourism Training Centre (PTTC), Pokhara, Nepal.

SNV, (2004). "Developing Sustainable Communities: A Toolkit for Development Practitioners", Netherlands Development Organisation, Kathmandu, Nepal, 2004

TRPAP (2001), Project Document, NEP/99/013

TRPAP (2007). Nepal's Experience Implementing Sustainable Rural Tourism Development Models: Lessons Learned, TRPAP (MoTCA/UNDP/DFID/SNV), Kathmandu, Nepal

UNDP (2004), Nepal Human Development Report, Empowerment and Poverty Reduction, Kathmandu.

UNDP (2005), Human Development Report, International Cooperation at a Crossroads: Aid, trade and security in an unequal world.

UNDP (2006), Nepal: Readings in Human Development, Kathmandu 